\title{
Covid-19 period and competences in higher education- study on cooperation and assertivity
}

\section{Periodo Covid-19 y competencias en la educación superior - estudio sobre cooperación y asertividad}

DOI: $10.46932 / \mathrm{sfjdv2n3-031}$

Received in: May 1st, 2021

Accepted in: Jun 30th, 2021

\author{
Sónia Alexandre Galinha \\ PhD in Psychology \\ Researcher at CIE_UMa Education Research Center at the University of Madeira, Portugal; \\ Higher School of Education, Polytechnic Institute of Santarém, Portugal. \\ E-mail: sonia.galinha@ese.ipsantarem.pt \\ Ricardo São-João \\ $\mathrm{PhD}$ in Life Sciences - Health of Populations/Biostatistics \\ Researcher at CEAUL_Centro de Estatística e Aplicações Universidade de Lisboa, Portugal; \\ School of Management and Technology, Polytechnic Institute of Santarém, Portugal \\ E-mail: ricardo.sjoao@esg.ipsantarem.pt
}

\begin{abstract}
Within this pandemic associated with Covid-19, psychological health occupies a prominent place as a result of a situation of forced isolation. Impacts can lead to an increase in mental health disorders as well as a set of adaptive reactions inherent to the recovery. Cooperation is conceived as the ability to jointly operationalize knowledge, attitudes and skills with a view to achieving a common purpose; and assertiveness is conceived as a bilateral behaviour that emphasizes the importance of considering the desires, thoughts and feelings of both the sender and the recipient of the assertive message, predictive of academic success. In this line, the main objective of this study is to present the results of the application of the Global Cooperation Assessment Scale (EAGC) and the findings levels of the Global Assertiveness Assessment Scale (EAGA). The study used a non-probabilistic sample for convenience of 101 Portuguese higher education students. EAGC and EAGA are a self-registration closed-ended Likert type 5 points, closed-response scales that allows assessing the degree of competence in respondents' cooperation and assertiveness. Both scales were administered online in spring semester 2019/2020, with the link to the questionnaire being made available to students the computer platform ensuring the response of a single survey per respondent whose participation in the study was voluntary. The treatment of the information, as well as its statistical analysis, was supported by the R software (R Core Team, 2020), having been assured the confidentiality and anonymity of the respondents. Sociodemographic variables were also used, which seemed promising in contextualizing, interpreting, and discussing the results. The value of the sample mean obtained at EAGC $=35( \pm 6.5)$, thus revealing a high capacity for cooperation and in the $\mathrm{EAGA}=31( \pm 5.53)$, thus revealing a high assertive competence who attend higher education.
\end{abstract}

Keywords: Assessment, EGAC, EGAA, Education, Psychology. 


\section{RESUMEN}

Dentro de esta pandemia asociada a Covid-19, la salud psicológica ocupa un lugar destacado como consecuencia de una situación de aislamiento forzoso. Los impactos pueden conducir a un aumento de los trastornos de salud mental, así como a un conjunto de reacciones adaptativas inherentes a la recuperación. La cooperación se concibe como la capacidad de operacionalizar conjuntamente conocimientos, actitudes y habilidades con vistas a lograr un propósito común; y la asertividad se concibe como un comportamiento bilateral que enfatiza la importancia de considerar los deseos, pensamientos y sentimientos tanto del emisor como del receptor del mensaje asertivo, predictor del éxito académico. En esta línea, el objetivo principal de este estudio es presentar los resultados de la aplicación de la Escala de Evaluación de la Cooperación Global (EAGC) y los niveles de hallazgos de la Escala de Evaluación de la Asertividad Global (EAGA). El estudio utilizó una muestra no probabilística por conveniencia de 101 estudiantes portugueses de educación superior. El EAGC y el EAGA son escalas de autorregistro cerrado tipo Likert de 5 puntos, de respuesta cerrada, que permiten evaluar el grado de competencia en cooperación y asertividad de los encuestados. Ambas escalas se administraron online en el semestre de primavera 2019/2020, poniendo a disposición de los estudiantes el enlace al cuestionario la plataforma informática que aseguraba la respuesta de una única encuesta por encuestado cuya participación en el estudio era voluntaria. El tratamiento de la información, así como su análisis estadístico, se apoyó en el software $\mathrm{R}$ ( $\mathrm{R}$ Core Team, 2020), habiéndose asegurado la confidencialidad y el anonimato de los encuestados. También se utilizaron variables sociodemográficas, que parecían prometedoras para contextualizar, interpretar y discutir los resultados. El valor de la media de la muestra obtenida en el EAGC $=35( \pm 6,5)$, revelando así una alta capacidad de cooperación y en el EAGA=31 $( \pm 5,53)$, revelando así una alta competencia asertiva que cursan estudios superiores.

Palabras clave: Evaluación, EGAC, EGAA, Educación, Psicología.

\section{INTRODUCTION}

The ongoing severe acute respiratory pandemic has caused nearly 500.000 detected cases of coronavirus disease (Covid-19) illness and claimed more than 20.000 lives in the world as of 26 March (Kissler, Tedijanto, Goldstein, Grad, \& Lipsitch, 2020). Within this pandemic associated with Covid-19, psychological health occupies a prominent place because of a situation of forced isolation. Impacts can lead to an increase in mental health disorders as well as a set of adaptive reactions inherent to the recovery. Public health and the well-being of higher education students deserved our attention.

Currently, there is a widespread and pronounced need for cooperation competence; therefore, several studies have been carried out on this theme, both in the field of learning. Conceptually, cooperation refers to the way in which individuals combine their strengths and their knowledge to achieve the same goal, in a proactive and participatory attitude by all. Empirical research data is needed to support the development of evidence-based strategies in order to reduce adverse psychological impacts and psychiatric symptoms. The competence of cooperation is thus the ability to operationalize knowledge, attitudes and skills to act together, with a view to achieving a common purpose. There are multiple advantages of collaborative work for the lives of schools (Formosinho \& Machado, 2008; Formosinho, 
2009; Kaendler, Wiedmann, Rummel \& Spada, 2015). According to Morin (2002, quoted by Cochito, 2004, p.3), "the human being must be both an individual, part of a society and part of a species".

The collaborative joint work provides the professional growth of the teachers involved in terms of improving reflective skills and enriching didactic knowledge, consequently leading to a change in teaching practices both in the classroom and outside. One of the teachers' strengths is the increase in joint reflection on the work carried out, which allows the construction of more articulated and contextualized teaching resources. For communities of practice, sharing information and researching new tools, it can cooperatively initiate a continuous teaching-learning and research process in the teaching context, inside and outside the classroom. The cooperative classroom emphasizes the regulatory assessment that tracks student progress and provides opportunities and tools for self-assessment. The teacher's concern is to provide permanent feedback and, in good time, give indications of what each student can do to improve, help him to recognize his strengths and weaknesses. Feedback based on an objective description of what was observed and which seeks to balance positive aspects and difficulties (Cochito, 2004).

According to Pereira, Motta, Vaz, Pinto, Bernardino, Melo, Ferreira, Rodrigues, Medeiros and Lopes (2006) the entrance to the University constitutes a moment of transition, which is a remarkable stage in the development of young people, requiring adaptations to new realities. Several studies have shown how much this adaptation and integration process can be in an academic context. Regarding the construction of communities of practice, Cochito (2004) defends two vectors: "learning throughout life" and "learning from life". The concept of literacy means not only the existence of knowledge, but also the competence to learn and whoever does not reveal this appetite for learning and for a permanent update will hardly be kept up to date. This relationship with knowledge implies not only the awareness of 'uncertainty' and 'temporality' of what is known, but also the awareness of what is not known and the ability to establish and regulate learning paths (Carneiro, 2001, cited by Cochito, 2004). These paths are not delineated without the relational dimension of learning and without active participation in peer learning groups. Whatever the context, the competence for cooperation is fundamental to the growth of people and educational system.

Assertiveness is conceived as a bilateral behaviour that emphasizes the importance of considering the desires, thoughts and feelings of both the sender and the recipient of the assertive message, predictive of academic success. The present investigation is also in line with that recommended by Jardim and Pereira (2006), in which improving the assertiveness competence presupposes a systematic learning process in which the needs of the person, the objective and the surrounding circumstances must be considered. There are several benefits of assertive competence as a person, student and professional future in the optimization of psychological resources. 
Based on this definition, attesting to three aspects related to assertiveness: it is not an innate competence, determined by the genetic code or someone's disability, but it has to do with behaviours - as such, it is characterized by being observable, measurable and amenable to modification; it is not a competence of the intrapersonal scope, since it interacts with the other, the situations and contexts in which these behaviours occur; it is a behaviour that refers to the effectiveness and satisfaction in social interactions, which results in the well-being of all interlocutors.

Assertiveness has become synonymous with social skills, as we can see in the definition of Caballo (1993), referring to them as a set of behaviours, taken by an individual in an interpersonal context, which expresses his feelings, attitudes, wishes, opinions or rights in a way that is appropriate to the situation, while also respecting these behaviours in others, and that usually resolves the immediate problems of the situation and minimizes the likelihood of future problems.

\section{METHODS}

\subsection{OBJECTIVE}

The main objective of this study is to present the results of the application of the Global Cooperation Assessment Scale (EAGC) and the findings levels of the Global Assertiveness Assessment Scale (EAGA), applied in the pandemic period in higher education.

\subsection{SAMPLE}

The study used a non-probabilistic sample for convenience of 101 Portuguese higher education students. As it is a non-probabilistic sampling for convenience, the authors did not use inferential statistics as a methodology due to the inherent limitations, but descriptive statistics. The sample of surveys received online consists mostly female $(88 \%)$. The average age is 21.25 years ( \pm 3.86 years), with the youngest and oldest student respectively 19 and 27 years old. Almost all respondents are single (98\%), with the rest being married.

Most students (50\%) live with their families, $26 \%$ with their friends, $13.5 \%$ other choose, and the lowest percentage of students lives in a residence/rented room (10.6\%).

When traveling to the educational establishment, the means of transport most used by students are: on foot (50\%), public transport (35\%), own car (23\%) and bicycle/scooter/skateboard (2\%). The median travel time from the student's address to the university is 20 minutes (inter-quartile range: 40 minutes). Additionally, it appears that in students who travel daily distances in each route greater than $30 \mathrm{~km}, 72 \%$ do so in public transport, the rest being by their own vehicle. Approximate distance, in Km, of the route (one way) that the student takes daily from his address to the educational institution during the class period: $54 \%<5 \mathrm{~km}$ travelling from address to university, $26 \%>30 \mathrm{~km}, 15 \% 10-29 \mathrm{Km}, 5 \% 5-9 \mathrm{~km}$. 


\subsection{INSTRUMENTS}

EAGC and EAGA are a self-registration closed-ended Likert type 5 points scales (1- never, 2rarely, 3-sometimes, 4- often, 5- always) that allows assessing the degrees of competence in respondents' cooperation and assertiveness (Jardim \& Pereira, 2006).

The EAGC, about cooperation variable, is composed of nine items, which are respectively: 1. When I work in a team I like to collaborate with colleagues; 2. I think that cooperation helps to develop new ideas; 3. When I work in a group, I feel that everyone's contribution is important; 4. I enjoy working in a group more than individually; 5. I appreciate teamwork, especially for the moments it provides; 6. The more I work in group with colleagues, the more I appreciate them; 7. Group work makes me enjoy attending my school; 8. I prefer group assessment versus individual assessment; 9. When I work in a group I have a higher income.

The EAGA is composed of eight items, which are respectively: 1. I usually express my ideas; 2. In a conflict situation, I usually know when to be firm and not to give in; 3. I usually defend my rights; 4. When they ask me for something it doesn't suit me, I know how to refuse; 5. When I disagree with someone, I express it convincingly; 6. I usually speak as long as necessary to state my views; 7. I usually speak in a clear and audible tone of voice; 8 . When I feel offended, I manifest it directly to the person who offended me.

\subsection{PROCEDURES}

EAGC and the EAGA were administered online in the spring semester of the academic year 2019/2020, with the questionnaire link being made available to students ensuring the computer platform answered a single confidence survey with the anonymity of the respondents ensured by a respondent whose participation and participation in the study was voluntary. The treatment of the information, as well as its statistical analysis, was supported by the R software (R Core Team, 2020).

\section{RESULTS}

The interpretation of the EAGC is directly related to the result of the sum of the values obtained in each of the items of the questionnaire for each individual. According to Jardim and Pereira (2006) values between 9 and 21 are a sign of low cooperation; values between 22 and 33 show an average capacity for cooperation; values between 34 and 45 show a high capacity for cooperation. In the present study, the value of the sample mean obtained for the 101 students of higher education at EAGC was $35( \pm 6.5)$, thus revealing a high capacity for cooperation in these students. 
Given the statement "When I work in a team I like to collaborate with my colleagues", almost all respondents (90\%) express frequent or immediate availability. When asked "When I work in a group, I feel that everyone's contribution is important" and "I think that cooperation helps to develop new ideas", respondents express a similar high agreement in their availability (87\%), slightly more pronounced in the first affirmation. Once asked "I appreciate teamwork, especially for the fun times it provides", $71 \%$ express that teamwork often brings or always associated with playful moments. It appears that in the following statements there is an increase in the standard of neutrality of respondents, varying from $28 \%$ to $40 \%$, since the answers are situated in the median of the scale (3- sometimes). In the statements "The more I work together with my colleagues, the more I value them" and "Working in a group makes me enjoy attending my school" the pattern in the responses is similar, with less consensus on the last statement (14\% versus 9\%). It appears that in the last three statements that refer to "better performance", "I like to work in a team" and "individual evaluation" the standard of neutrality is equal to or greater than $40 \%$, although there is a higher percentage in the pattern of responses with the levels often (4) and always (5) higher than the levels never (1) and rarely (2). The last statement, which refers to the type of assessment (individual versus group) seems to be the one with the least consensus since the difference between the most extreme levels of the scale is only $11 \%$. We found that the students surveyed indicate a greater preference for activities/initiatives that involve cooperation and carried out as a team. In a detailed reading of the percentage of responses in each item of the EAGC in its five levels, it should be noted that the said statements present high average values $(\geq 4.48$ values $)$ with reduced associated standard deviations $(\leq 0.8)$ causing the coefficients of variation to be reduced $(\leq 17.7 \%)$ indicating that these averages are representative. Despite the fact that, in global terms and in particular for each of the items of the EAGC, the average values are always higher than the standard of neutrality (3-times) revealing the capacity for cooperation, in the statements whose percentage of responses is higher in the median of the scale (between $40.4 \%$ and $44.4 \%$ ) a higher percentage of disagreements converges (between $14.1 \%$ and $24.3 \%$ ).

In what concerns EAGA, in view of the statement "I usually defend my rights", $84 \%$ of students are often demonstrative (37\%) or always assertive (47\%), $12 \%$ are neutral, while only $4 \%$ are never assertive (1\%) or rarely (3\%). It is noteworthy that this was the EAGA item where students were always more assertive (47\%). When asked "I tend to speak in a clear and audible tone", $73 \%$ of students are often assertive $(48 \%)$ or always assertive $(25 \%), 22 \%$ are neutral in assertiveness, while $5 \%$ are rarely be assertive. This was the EAGA item where students were often more assertive (48\%). Students demonstrate identical neutrality (26\%) when confronted with the items "I usually express my ideas" and "When I disagree with someone, I express it convincingly". In none of the referred items was there no absence of assertiveness. The frequencies of demonstration of rare assertiveness are similar (4\% and 7\%) as well as 
in the demonstration of frequent and full assertiveness (70\% vs 67\%). With regard to the items "In a conflict situation, I usually know when I must be firm and I must not give in" and "I normally speak the time necessary to express my opinions", both total $66 \%$ of the responses concentrated at the frequent levels $(44 \%)$ or always assertive (22\%). In this same set of items, there is an $8 \%$ higher neutrality of assertiveness in the first item, respectively, accompanied by an equal decrease in the absence of assertiveness. In the last statement "When I am asked for something that does not suit me, I know how to refuse" is the one where the greatest demonstration of neutrality (35\%) in assertiveness has been registered. This statement together with "When I feel offended, I manifest it directly to the person who has offended me" presents substantially the same response pattern with respect to a frequent or always present demonstration of assertiveness; however, it is distinguished by presenting a value that more than doubles with respect to a rare or absent demonstration of assertiveness (13\% vs 6\%). In a detailed reading of the percentage of responses in each item of EAGA in its five levels. Its reading is aided by a caption. The greater the percentage of responses given at each level of the scale, the greater the approximation to the lilac color. In the first column, in gray, the average of responses to each EAGA item is shown with the respective standard deviation in parentheses. The percentage of students who did not demonstrate assertiveness (1-Never) is residual. In global terms and in particular for each of the items of the EAGA, the values of the sample means are always higher than the standard of neutrality (3-times) revealing an approach to the demonstration of frequent assertiveness, a fact corroborated by a higher rate of level responses (4-often). The item "I usually defend my rights" stands out from the others for presenting a higher sample average (4.25) associated with a low dispersion (0.86), substantiating itself in the item with the demonstration of higher assertiveness.

\section{CONCLUSIONS AND DISCUSSION}

The value of the sample mean obtained at $\mathrm{EAGC}=35( \pm 6.5)$, thus revealing a high capacity for cooperation and in the EAGA=31 $( \pm 5.53)$, thus revealing a high assertive competence who attend higher education (R Core Team, 2020).

Sociodemographic aspects present in the sample, such as: young age group, school level above the mandatory level, living together with the family during the period of classes, may be protective factors with regard to maintaining higher levels of cooperation and assertiveness. In the exceptional period of public health (Covid-19 confinement) to which the study refers, respondents in distance learning regimes showed levels of assertiveness above average. The future possibility of being able to use probabilistic methods, will allow to determine the influence of these variables. 
Social skills that occur with high frequency and little variability can be considered as patterns, suggesting characteristics of culture or subculture that are important in selecting assessment tools and planning interventions (Del Prette, Del Prette, Barreto, Bandeira, Rios-Saldaña, Ulian, Gerk-Carneiro, Falcone, \& Villa (2004).

Thus, it is necessary to continue to study tutoring in distance education in the time of Covid-19 in the current scenario. The virtual learning environment allows the teacher to develop a teaching situation, mediated by technological devices and the personal and social skills of students and teachers cannot be forgotten. This new way of teaching with computer didactic resources requires preparation and activity planning that provides opportunities for active learning that have meaning for both the student and the teacher (Camacho, Joaquim, Menezes \& Sant'Ana, 2020).

To develop the competences of cooperation and assertiveness, systematic training in which the individual learns and exercises competence has been shown to be effective by authenticity through regular practice. Act as a group to achieve the end that brought them together, cooperating, expressing feelings and emotions effectively is necessary in a behavioural dimension (the type of skill), a personal dimension (cognitive variables) and a situational dimension (the environmental context).

For the development of cooperation and assertiveness, several programs have been planned and implemented in the form of skills training in the field of promoting personal and social skills, also with the objective of primary prevention. There are thus valid reasons for stimulating competences even in a situation of social isolation for quality of life, mental health and academic success to enhance rewarding and successful social relationships.

\section{ACKNOWLEDGEMENT}

This work is partially financed by national funds through Fundação para a Ciência e a Tecnologia- FCT under the project UIDB/00006/2020. 


\section{REFERENCES}

Caballo, V. E. (1993). Manual de evaluación y entrenamiento en habilidades sociales. Madrid: Siglo Veintiuno.

Camacho, A.; Joaquim, F.; Menezes, H.; Sant'Ana, R. (2020). Tutoring in distance education in times of COVID-19: relevant guidelines. Research, Society and Development, vol. 9, n.5, e30953151, ISSN 25253409. Doi: http://dx.doi.org/10.33448/rsd-v9i5.3151

Carneiro, R. (2001). Fundamentos da educação e da aprendizagem: 21 ensaios para o século 21. Lisboa: Fundação Manuel Leão.

Cochito, M.I. (Coord). (2004). Cooperação e Educação Intercultural. Cadernos de Formação 3. Lisboa: ACIME - Alto Comissariado Para a Imigração e Minorias Étnicas. Retrieved from https://www.cidadaniaemportugal.pt/wp-content/uploads/recursos/cooperacao-e-aprendizagem.pdf

Del Prette, Z., Del Prette, A.; Barreto, M. C. M.; Bandeira, M.; Rios-Saldaña, M. R.; Ulian, A. L. A.; Gerk-Carneiro, E.; Falcone, E.; \& Villa, M. B. (2004). Psicologia: Reflexão e Crítica, 2004, 17(3), pp.341-350.

Formosinho, J. \& Machado, J. (2008). Currículo e organização as equipas educativas como modelo de organização pedagógica. Revista Currículo sem Fronteiras, 8 (1). 5-16.

Formosinho, J. (Coord). (2009). Formação de Professores. Aprendizagem profissional e ação docente. Porto: Porto Editora.

Jardim, J. \& Pereira, A. (2006). Manual de Competências Pessoais e Sociais-Guia Prático para a mudança positiva. Porto: Porto Editora.

Kaendler, C.; Wiedmann, M.; Rummel, N.; \& Spada, H. (2015). Teacher competencies for the implementation of collaborative learning in the classroom: a framework and research review, Educational Psychology Review, 27: 505-536.

Kissler, S.; Tedijanto, C.; Goldstein, E.; Grad, Y.H.; \& Lipsitch, M. (2020, may 22). Coronavirus Projecting the transmission dynamics of SARS-CoV-2 through the postpandemic period. Science: Vol. 368, Issue 6493, pp. 860-868. Doi: 10.1126/science.abb5793

Morin, E. (2002). Os sete saberes necessários à educação do futuro. Lisboa: Piaget.

Pereira, A; Motta, E; Vaz, A.; Pinto, C.; Bernardino, O.; Melo, A.; Ferreira, J.; Rodrigues, M.J.; Medeiros, A. \& Lopes, P. (2006). Sucesso e desenvolvimento psicológico no Ensino Superior: Estratégias de intervenção. Revista Análise Psicológica v.24 n.1. Retrieved from http://www.scielo.mec.pt/scielo.php?script=sci_arttext\&pid=S0870-82312006000100006

$\mathrm{R}$ Core Team (2020). R: A language and environment for statistical computing. $\mathrm{R}$ Foundation for Statistical Computing, Vienna, Austria. Retrieved from https://www.R-project.org/

Radmila, M. (2019, april 30). Effects of an Assertive Behavior Program on the Reduction of Anxiety in Future Teachers and Preschool Teachers. Psychology \& Psychological Research International Journal, Volume 4 Issue 2 Doi: 10.23880/pprij-16000202ISSN: 2576-0319 